University of Nebraska - Lincoln

DigitalCommons@University of Nebraska - Lincoln

January 2005

\title{
A REVIEW OF THE SOUTH AMERICAN GENUS HOPLOPYGOTHRIX SCHÜRHOFF (COLEOPTERA: SCARABAEIDAE: CETONIINAE: GYMNETINI)
}

Brett C. Ratcliffe

University of Nebraska-Lincoln, bratcliffe1@unl.edu

Follow this and additional works at: https://digitalcommons.unl.edu/entomologypapers

Part of the Entomology Commons

Ratcliffe, Brett C., "A REVIEW OF THE SOUTH AMERICAN GENUS HOPLOPYGOTHRIX SCHÜRHOFF (COLEOPTERA: SCARABAEIDAE: CETONIINAE: GYMNETINI)" (2005). Papers in Entomology. 33.

https://digitalcommons.unl.edu/entomologypapers/33

This Article is brought to you for free and open access by the Museum, University of Nebraska State at DigitalCommons@University of Nebraska - Lincoln. It has been accepted for inclusion in Papers in Entomology by an authorized administrator of DigitalCommons@University of Nebraska - Lincoln. 


\title{
A Review of the South American Genus Hoplopygothrix Schürhoff (Coleoptera: Scarabaeidae: Cetonitnae: Gymnetini)
}

\author{
BRETT C. RATCLIFFE \\ Systematics Research Collections \\ W436 Nebraska Hall \\ University of Nebraska State Museum \\ Lincoln, NE 68588-0514, U.S.A. \\ bratcliffe1@unl.edu
}

\begin{abstract}
The southern Brazilian genus Hoplopygothrix is reviewed. The genus now contains only one species, H. atropurpurea (Schaum). Hoplopygothrix atropurpurea nigroscutellaris (Moser) and $H$. fulvohirta (Moser) are placed in synonymy with $H$. atropurpurea.
\end{abstract}

They are not aristocratic, vain esoterics like butterflies or moths or communists like ants and bees. They're not filthy, opportunistic carpetbaggers like flies. They are professional, with a skill. They' re built for a job and get down to it without boastfulness or hysteria. And there is nowhere that, sooner or later, doesn't call for a beetle to set up shop and get things done.

—A. A. Gill, Sunday Times Magazine, April 2002

The cetoniine tribe Gymnetini currently comprises 25 genera in the New World (Krikken 1984; Krajcik 1998) distributed from the southern United States south to Argentina (Blackwelder 1944). The monotypic genus Hoplopygothrix is known only from southeastern Brazil, and it is reviewed here.

Schaum (1841) described Gymnetis atropurpurea based on two female specimens from Brazil. Moser (1910) described what he termed a "subspecies" of Schaum's species, G. atropurpurea nigroscutellaris, and he based this on two specimens from Theresopolis, Brazil; these two specimens had a black, rather than tawny, tuft of setae covering the tip of the scutellum at the end of the basomedian lobe. In the same paper, Moser also described G. fulvohirta based on a single female (also from Theresopolis, Brazil), and he distinguished it from G. atropurpurea by its yellowish setae, rather than the black setae of $G$. atropurpurea.

Bourgoin (1916) described Gymnetis rugosa based on a single female from Brazil. The published description of the type indicates it is from "Minas Geraes" (present day state of Minas Gerais), whereas the holotype at the BMNH is labeled "Mineiros, Goyas" (present day state of Goias). I believe that the label on the specimen, with point-locality data, is the most accurate, and that it could have been incorrectly transcribed "Minas Geraes" for the publication.

Schürhoff (1933) then created the genus Hoplopygothrix for G. atropurpurea Schaum, thus fixing this species as the type species of Hoplopygothrix by monotypy. Schürhoff was evidently unaware of Moser's (1910) paper published 23 years earlier describing a subspecies of $G$. atropurpurea, and he did not include this taxon in the genus.

Schürhoff (1937) placed G. fulvohirta in Hoplopygothrix and also synonymized $G$. rugosa with $H$. atropurpurea. Inasmuch as no systematist has examined these taxa or their types since then, this classification has been the status quo (Blackwelder 1944; Krikken 1984; Krajcik 1998). 


\section{Methods}

The results of this study were based upon the examination of 85 specimens received on loan from institutions and private collections. Specimens of Hoplopygothrix are poorly represented in ALL collections, thus attesting to their relative rarity in nature. The collections and their acronyms (as given in Arnett et al. 1993) are as follows. The curators and/or collection managers who provided the material are also indicated.

AMIC Antonio Martínez Collection then at Salta, Argentina (currently at the Canadian Museum of Nature, Ottawa, Canada).

AMNH American Museum of Natural History, New York, NY (Lee Herman, Jr.).

BCRC Brett C. Ratcliffe Collection, Lincoln, NE.

BMNH The Natural History Museum, London, England (Malcolm Kerley, Michael Bacchus).

CASC California Academy of Sciences, San Francisco, CA (Norman Penny, David Kavanaugh).

DEIC Deutsches Entomologisches Institut, Eberswalde, Germany (Lothar Zerche).

FMNH Field Museum of Natural History, Chicago, IL (Al Newton).

MGFT Georg Frey Collection then at the Zoologische Staatssammlung, Munich, Germany (Gerhard Scherer, Max Kuhbandner), now at the Naturhistorisches Museum, Basel, Switzerland (Daniel Burkhardt).

MLUH Martin Luther Universität, Halle, Germany (Manfred Dorn).

MNHN Museum National d'Histoire Naturelle, Paris, France (Jean Menier, Roger-Paul Dechambre).

MHNG Museum d'Histoire Naturelle, Geneva (Ivan Löbl).

MZSP Museu de Zoologia da Universidade de São Paulo, São Paulo, Brazil (Cleide Costa).

NMPC National Museum of Natural History, Prague, Czech Republic (Josef Jelínek).

QBUM Museu Naçional, Rio de Janeiro, Brazil (Miguel Monné).

RMNH Nationaal Natuurhistorische Museum Leiden, the Netherlands (Jan van Tol, Jan Krikken).

SEAB Carlos Seabra Collection, Rio de Janeiro, Brazil (Carlos Seabra).

UCCC Universidad de Concepcíon, Concepcíon, Chile (Jorge Artigas).

USNM U.S. National Museum, currently at University of Nebraska State Museum.

ZMHU Museum für Naturkunde, Berlin, Germany (Manfred Uhlig, Joachim Schulze, Hella Wendt).

ZSMC Zoologische Staatssammlung, Munich, Germany (Gerhard Scherer, Max Kuhbandner).

The generic and species descriptions were based on the following characteristics: length (from apex of pronotum to apex of elytra; the head and pygidium are not included in the length measurement because they can be variably deflexed), color and markings, interocular width (number of transverse eye diameters across the frons), form and sculpturing of the frons, clypeus, antennae, pronotum, mesepimeron, elytra, pygidium, legs, venter (mesometasternal process, abdominal sternites), and parameres.

Geographical localities are arranged alphabetically by state within Brazil and then alphabetically by locality within each state. Temporal data is provided, but these data should be used with caution because many specimens in old collections lack these data. 
I utilize the Phylogenetic Species Concept as outlined by Wheeler and Platnick (2000). This concept defines species as the smallest aggregation of (sexual) populations diagnosable by a unique combination of character states.

\section{Hoplopygothrix Schürhoff, 1933}

Type Species. Gymnetis atropurpurea Schaum, 1841: 48, by monotypy.

Description. Scarabaeidae, Cetoniinae, Gymnetini. Form: Rhomboidal, robust, sides slightly tapering toward apex of elytra, dorsum nearly flat. Color on dorsum velutinous black to dark reddish brown, venter shiny black. Surface of head, pronotum, elytra, and pygidium with distinct setae. Head: Shape subrectangular, longer than wide. Clypeus with apex beaded, emarginate, lobes either side of emargination rounded. Antenna 10-segmented, club subequal in length to segments 2-7. Pronotum: Shape subtrapezoidal, widest near base, gradually convergent to anterior angles, centerbase produced into posteriorly projecting lobe, lobe covering all but tip of scutellum, tip obscured by dense tuft of setae. Elytra: Widest at base, posthumeral emargination distinct, sutural costa elevated in posterior half. Pygidium: Surface punctate and/or with transverse, vermiform strigulae. Legs: Foretibia in males bidentate, teeth widely separated. Foretibia in females tridentate, teeth subequally spaced, middle tooth often reduced, occasionally obsolete. Venter: Mesometasternal process short, flat, apex rounded, nearly in same plane as longitudinal axis of body. Male abdominal sternites 1-5 deeply, longitudinally sulcate at middle; sternites in female simple, not sulcate.

Diagnosis. The following combination of characters distinguish Hoplopygothrix: head, pronotum, elytra, and pygidium with dense, short setae; color of dorsum velutinous black to dark reddish brown; clypeal apex beaded; foretibia bidentate in male, weakly tridentate in female; males with sternum longitudinally sulcate.

Hoplopygothrix is similar to Neocorvicoana Ratcliffe and Mico because they are both setose dorsally, a character not found in other genera of New World Gymnetini. They differ in that Hoplopygothrix has a marginal bead on the apex of the clypeus (Neocorvicoana does not), bidentate foretibia in the male (tridentate in Neocorvicoana), normally slender tarsomeres in the female (very short and compact in Neocorvicoana), and males with longitudinally sulcate abdominal sternites (normally convex in Neocorvicoana). Hoplopygothrix is easily separated from Hoplopyga (both with a beaded clypeal apex), because Hoplopygothrix is setose dorsally and Hoplopyga is glabrous.

Distribution. Southern Brazil.

\section{Hoplopygothrix atropurpurea (Schaum)}

(Figs. 1-3)

Gymnetis atropurpurea Schaum 1841: 48. Lectotype (here designated to stabilize the nomenclature) female at the Museum d'Histoire Naturelle (MHNG) (Geneva) and labeled: "BRAZIL" and with my red lectotype label. Single female paralectotype with same data also at MHNG and with my yellow paralectotype label.

Gymnetis fulvohirta Moser 1910: 295 (NEW SYNONYMY). Holotype female at the Museum für Naturkunde (Berlin) and labeled: (a) "Brasilia, Theresopolis, St. Catarina," (b) "fulvohirta Mos., Type," (c) female symbol, and (d) with my red holotype label.

Gymnetis atropurpurea nigroscutellaris Moser 1910: 296 (NEW SYNONYMY). Two probable syntypes at the Museum für Naturkunde (Berlin) and labeled: "Theresopolis, St. Catarina" [Brazil].

Gymnetis rugosa Bourgoin 1916: 199. Holotype female at The Natural History Museum (BMNH) (London) and labeled: (a) "Mineiros, Goyas, Brazil," (b) "Gymnetis rugosa Bourg., Type," female symbol, (c) "Bourgoin Coll.," and (d) with my red holotype label. 


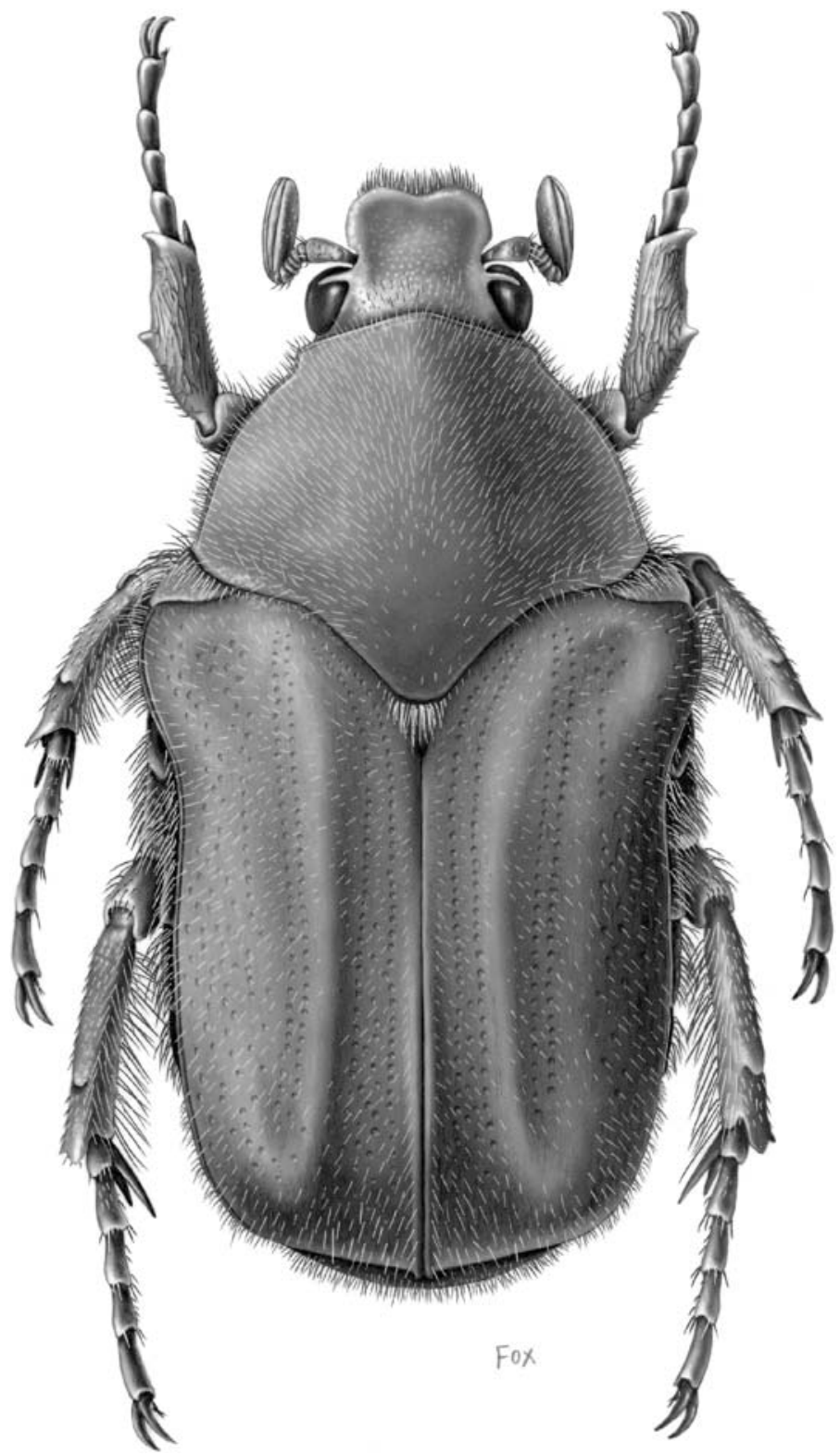

Fig. 1. Habitus of Hoplopygothrix atropurpurea (Schaum).

Description. Head: Color black, shining. Surface moderately to densely punctate; punctures moderate to large, setigerous; setae short to moderate in length, black to dark brown to tawny, less dense on clypeus. Clypeus with apex beaded, broadly truncate, slightly reflexed, center emarginate, anterior angles broadly rounded. Interocular width equals 4.5-5.0 transverse eye diameters. 

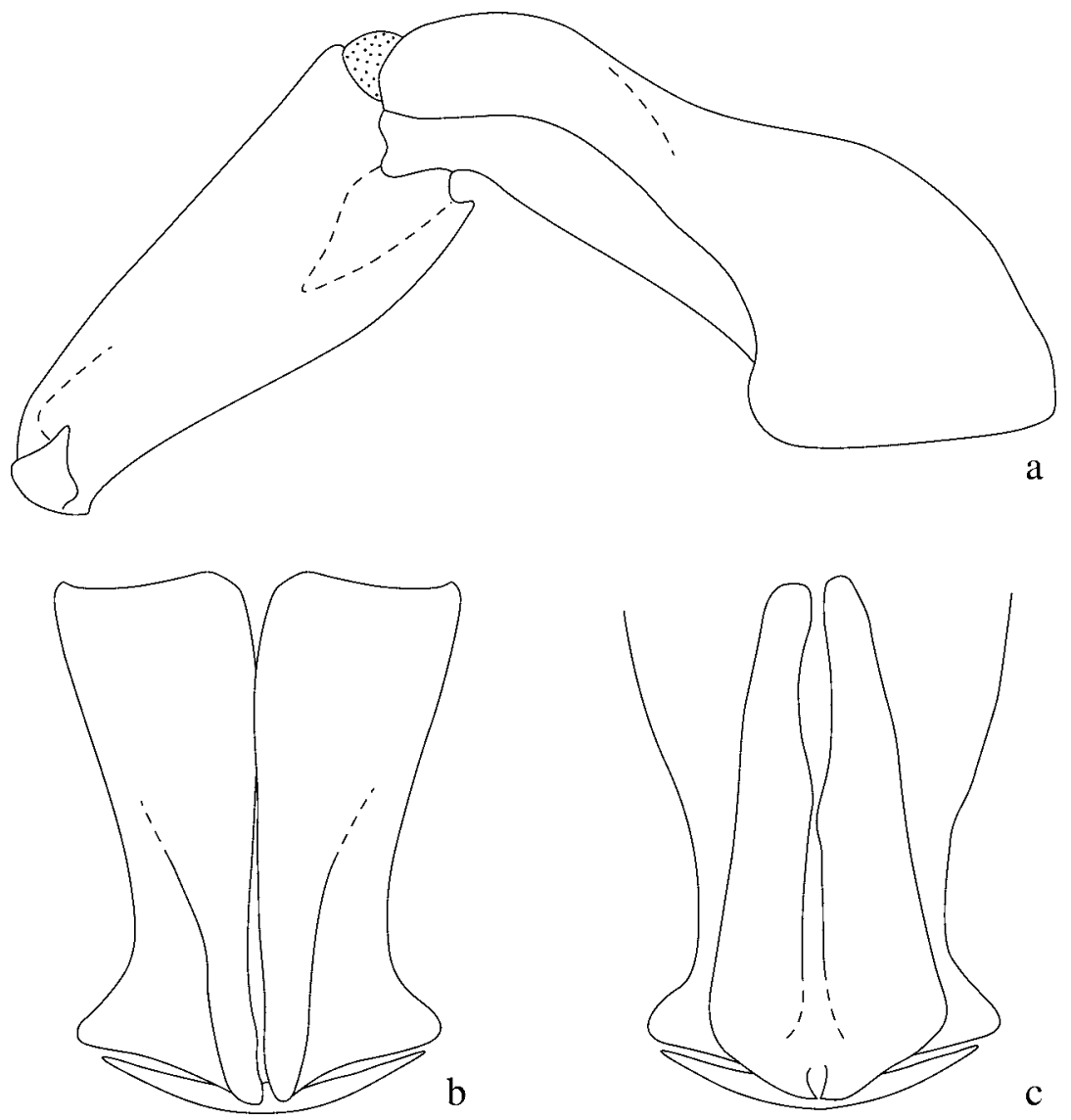

Fig. 2. Parameres of Hoplopygothrix atropurpurea: (a) lateral view, (b) dorsal view, (c) ventral view.

Antenna 10-segmented, club subequal in length to segments 2-7. Pronotum: Color black, opaque. Surface moderately densely punctate on disc, densely punctate on sides; punctures small to moderate in size, becoming larger in anterior angles, round to $\cap$-shaped, often confluent, setigerous; setae dense, moderately long, dark brown to tawny. Epimera with surface similar to that of pronotum. Lateral margin with distinct bead. Scutellum at apex with dense tuft of yellowish (most common) to dark brown setae. Elytra: Color dark reddish brown, opaque; punctures and rugae (especially on disc) piceous. Surface on disc varies from indistinctly punctate (punctures small, shallow) or distinctly punctate (punctures small, moderately dense) OR with 2 longitudinal bands of longitudinal, vermiform rugae, all setigerous; apex and sides with round or crescent-shaped punctures; setae moderate to long, dark brown to tawny, mostly recumbent, more or less in longitudinal bands on median $2 / 3$ of each elytron, becoming dense at apex; apical umbone prominent; apices weakly acute to spiniform, usually obscured by dense setae. Lateral margin with distinct bead. Pygidium: Color dark reddish brown to piceous or black, opaque, sometimes with cream-colored flecks at base, apex, and corners. Surface with concentrically vermiform punctures to densely, transversely rugopunctate, setigerous; setae dense, long, recumbent, tawny to dark brown. In lateral view, surface nearly flat in male, weakly convex in female. Venter: Color black, occasionally reddish brown, shining; sometimes abdominal sternites $1-4$ with small, cream-colored 


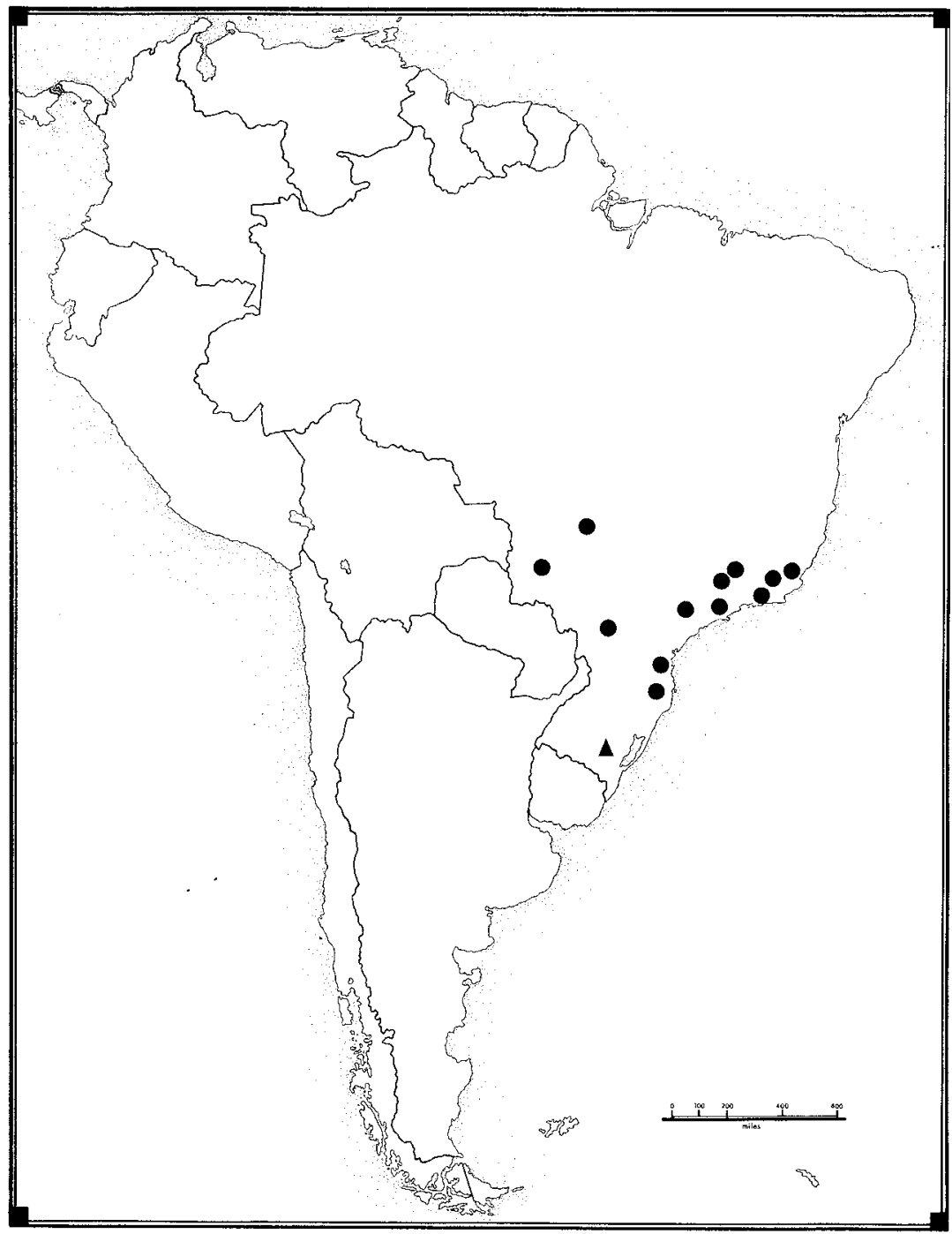

Fig. 3. Distribution of Hoplopygothrix atropurpurea. Triangle symbol denotes state record only.

spot on lateral edge at apex. Thoracic sternites with dense, long, dark reddish brown to tawny setae. Mesometasternal process flat, relatively short (not reaching procoxae), apex shining and evenly rounded. Abdominal sternites punctate or rugose on lateral thirds; sternites 1-5 in males deeply, longitudinally sulcate, females with sternites normally convex and with weakly impressed, longitudinal center line (best seen with oblique lighting). Last sternite setigerously punctate, setae black to tawny, short. Legs: Color black to dark reddish brown, shining. Foretibia in males bidentate, tridentate in females. Posterior tibia with 2 apical spurs with apices acute in males, rounded in females. Parameres: Figure 2. 
Distribution. 85 specimens examined from AMIC, AMNH, BCRC, BMNH, CASC, DEIC, FMNH, MGFT, MHNG, MLUH, MNHN, MHNG, MZSP, NMPC, QBUM, RMNH, SEAB, UCCC, USNM, ZMHU, ZSMC.

BRAZIL (85) GOIAS (4): Mineiros, Rio Verde; MINAS GERAIS (8): Maria da Fe', Poças de Coldas; PARANA (4): Caviúna, Rolandia; RIO DE JANEIRO (11): Jabaquara, Novo Friburgo, Rio de Janeiro; RIO GRANDE DO SUL (1): No data; SANTA CATARINA (6): Joinville, Theresopolis; SÃO PAULO (13): Cantareira, Piracicaba, São Paulo; NO DATA (38).

Temporal Distribution. January (2), February (3), June (1), October (3), November (10), December (5). Too few specimens have label data with the month of collection to portray a reliable temporal distribution other than during a southern hemisphere summer.

Biology. Nothing is known of the biology of this species, either from the literature or on specimen labels.

\section{Acknowledgments}

I am grateful to the curators and collection managers mentioned in the "Methods" section for their generous cooperation in either loaning or allowing me access to specimens under their care. Alexander Riedel (Staatliches Museum für Naturkunde, Karlsruhe, Germany) kindly translated from the German a technical description. Angie Fox (Scientific Illustrator, University of Nebraska State Museum) is acknowledged for her fine illustrations. I thank Mary Liz Jameson (University of Nebraska State Museum) and two anonymous reviewers for their constructive criticism of the manuscript. This project was supported by an NSF/PEET grant (DEB-0118669) to M. L. Jameson and B. C. Ratcliffe.

\section{Literature Cited}

Arnett, R. H., Jr., G. A. Samuelson, and G. M. Nishida. 1993. The insect and spider collections of the World. Sandhill Crane Press, Gainesville, FL. 310 pp.

Blackwelder, R. E. 1944. Checklist of the coleopterous insects of Mexico, Central America, the West Indies, and South America. Bulletin of the U.S. National Museum 185:189-341.

Bourgoin, A. 1916. Description de deux Gymnetis nouveaux du Brésil (Col. Scarabaeidae). Bulletin de la Société Entomologique de France 1916, No. 12:198-200.

Krajcik, M. 1998. Cetoniidae of the World. Catalogue-Part 1. Published by the author, Most, Czech Republic. 96 pp. plus indices.

Krikken, J. 1984. A new key to the suprageneric taxa in the beetle family Cetoniidae, with annotated lists of the known genera. Zoologische Verhandelingen No. 210:1-75.

Moser, J. 1910. Beitrag zur Kenntnis der Cetoniden. (Col.). VII. Deutsche Entomologische Zeitschrift 1910:293-301.

Schaum, H. R. 1841. Analecta entomologica (Dissertatio inauguralis). Halis Saxonum. 49 pp.

Schürhoff, P. N. 1933. Beiträge zur Kenntnis der Cetoniden III. Entomologisches Nachrichtenblatt 7:89-96.

Schürhoff, P. N. 1935. Beiträge zur Kenntnis der Cetoniden (Col.) VII. Mitteilungen der Deutschen Entomologischen Gesellschaft 6:21-28.

Schürhoff, P. N. 1937. Beiträge zur Kenntnis der Cetoniden (Col.). VIII. Revision der Gattung Gymnetis MacLeay. Deutsche Entomologische Zeitschrift 1937:56-80.

Wheeler, Q. D., and N. I. Platnick. 2000. The phylogenetic species concept (sensu Wheeler and Platnick) [p. 55-69]. In: Species concepts and phylogenetic theory. A Debate (Q. D. Wheeler and R. Meier, editors). Columbia University Press, NY. 230 pp.

(Received 27 July 2004; accepted 14 December 2004. Full page charges borne by the author. Publication date 19 April 2005.) 